\title{
Analisis Reaksi Pasar Sebelum dan Sesudah Pengumuman Kemenangan Donald Trump Menjadi Presiden Amerika Serikat
}

\author{
I Made Deva Hasdwi Putra ${ }^{1}$ \\ I Gusti Ayu Made Asri Dwija Putri \\ ${ }^{1}$ Fakultas Ekonomi dan Bisnis Universitas Udayana (Unud), Bali, Indonesia \\ email: devahasdwi@gmail.com/telp: +6281337899126 \\ ${ }^{2}$ Fakultas Ekonomi dan Bisnis Universitas Udayana (Unud), Bali, Indonesia
}

\begin{abstract}
ABSTRAK
Penelitian ini berbentuk event study dan bertujuan untuk menguji ada atau tidaknya kandungan informasi yang membuat pasar bereaksi pada saat pengumuman kemenangan Donald Trump menjadi presiden Amerika Serikat sebelum dan sesudah tanggal peristiwa, yang diukur menggunakan rata-rata abnormal return dan rata-rata trading volume activity. Sampel yang digunakan yaitu perusahaan-perusahaan yang tergolong Indeks KOMPAS100 periode Agustus-Januari 2017. Periode pengamatan yang digunakan yaitu selama 15 hari. Teknik analisis yang digunakan yaitu uji wilcoxon signed ranks test. Hasil yang diperoleh menunjukkan terdapat perbedaan rata-rata abnormal return dan rata-rata trading volume activity sebelum dan sesudah pengumuman kemenangan Donald Trump menjadi presiden Amerika Serikat. Hal ini menunjukkan terdapat kandungan informasi pada persitiwa pengumuman kemenangan Donald Trump menjadi presiden Amerika Serikat yang membuat pasar bereaksi.
\end{abstract}

Kata Kunci: Abnormal return, trading volume activity, event study

\begin{abstract}
This study is in the form of an event study and aims to examine the presence or absence of information content that makes the market react at the announcement of Donald Trump's victory as president of the United States before and after the event date, measured using average abnormal return and average trading volume activity. The sample used are companies that belong to KOMPAS100 Index period AugustJanuary 2017. Observation period used is for 15 days. Analytical technique used is test wilcoxon signed ranks test. The results show that there are differences in average abnormal return and average trading volume activity before and after the announcement of Donald Trump's victory as president of the United States. This shows that there is information on the announcement of Donald Trump's victory to become president of the United States that makes the market react.

Keywords: Abnormal return, trading volume activity, event study
\end{abstract}

\section{PENDAHULUAN}

Pasar modal merupakan wadah atau sarana bagi investor dalam berinvestasi jangka panjang serta melakukan upaya diversifikasi, penyebaran kepemilikan perusahaan, bahkan menciptakan iklim usaha yang sehat melalui keterbukaan informasi (Purnamawati dan Werastuti, 2013:16). Tandelilin (2010:26) menyatakan pasar modal sebagai tempat bertemunya investor dengan perusahaan 
yang secara umum melakukan transaksi jual beli saham. Pasar modal adalah suatu bidang usaha perdagangan surat-surat berharga seperti saham, sertifikat saham, dan obligasi (Anoraga dan Pakarti, 2001:7). Menurut Usman Marzuki (1989), pasar modal adalah pelengkap disektor keuangan terhadap dua lembaga lainnya yaitu bank dan lembaga pembiayaan. Pasar modal bertindak sebagai penghubungantara para investor dengan perusahaan ataupun institusi pemerintah melalui perdagangan instrumen melalui jangka panjang seperti obligasi, saham, dan lainnya. Anoraga dan Pakarti (2003:12) menyatakan pasar modal memberikan manfaat bagi investor berupa dividen bagi mereka yang memiliki atau memegang saham dan bunga tetap atau bunga yang mengambang bagi pemegang obligasi. Investor dapat melakukan diversifikasi investasi di pasar modal dalam bentuk portofolio yang disesuaikan dengan tingkat return yang diinginkan serta memiliki risiko masing-masing.

Pasar modal tidak dapat dilepaskan dari berbagai faktor yang dapat mempengaruhinya antara lain faktor ekonomi dan faktor non ekonomi (Hengky, dkk, 2014). Faktor ekonomi meliputi tingkat inflasi, pembagian deviden, tingkat suku bunga deposito, sedangkan faktor non ekonomi meliputi keamanan Negara dan peristiwa politik. Brunner (2009) menyatakan cara lain mempengaruhi perekonomian adalah melalui kebijakan, ekonomi beroperasi dalam kerangka politik dan bereaksi terhadap perubahan tersebut.

Pemilihan umum presiden di Amerika Serikat baru saja dilaksanakan pada tanggal 8 November 2016. Pemilihan umum presiden Amerika Serikat yang diselenggarakan ke-58 kalinya dimenangkan oleh Donald Trump. Sosok Donald 
Trump yang fenomenal dikhawatirkan akan mempengaruhi perekonomian di Indonesia jika terpilih menjadi presiden Amerika Serikat. Pada pidato kampanyeDonald Trump terus mengungkapkanrencananya membatalkan segala perjanjian perdaganganyang dianggap akan merugikanAmerika Serikat. Jika kebijakan inidilakukan, maka Indonesia akan menjadi salah satu negara yang akan terkenadampak dari kebijakan tersebut. Kebijakan Trump yang cenderung anti globalisasi dan anti liberalisasi perdagangan itu dikhawatirkan akan menyulut perang dagang antarnegara yang ujungnya akan menimbulkan ketidakstabilan ekonomi global. Perdagangan Selasa (8/11/2016), IHSG ditutup melesat 1,57\% sebesar 84,47 poin ke level $5.470,68$ seiring penguatan lantai bursa di Asia Pasifik. IHSG kembali menjadi jawara di antara bursa utama dunia dengan penguatan 19,11\% sepanjang tahun berjalan (www.kompas.com). Hal ini membuktikan pasar merespon positif pemilu Amerika Serikat.

Seiring perhitungan suara pemilihan presiden Amerika Serikat (AS), dan calon presiden dari partai Republik Donald Trump berpotensi menang membuat bursa berjangka Amerika Serikat (AS) tertekan. Bursa saham global pun bergejolak. Tak hanya saham tetapi juga mata uang dan obligasi. Investor bereaksi terhadap kemungkinan calon presiden dari partai Republik AS tersebut dapat mengalahkan Hillary Clinton. Indeks saham Dow Jones berjangka turun sekitar 800 poin atau 4,4\%. Apabila Dow Jones tetap melemah maka mendorong indeks saham Dow Jones menembus level terendahnya sejak 24 Juni. Dengan keunggulan Donald Trump juga mendorong kecemasan besar di pasar keuangan dunia. Investor dipaksa untuk mempertimbangkan kejutan dari pemilihan presiden 
AS (www.liputan6.com). Sejalan dengan bursa di kawasan Asia dilansir dari (www.bisnis.com), Indeks harga saham gabungan (IHSG) turun tajam 112,48 poin atau $-2,06 \%$ ke level 5.358,20 di akhir sesi I perdagangan hari ini. Sepanjang hari, IHSG bergerak di kisaran 5.358,09-5.491,70. Seluruh bursa saham regional memerah. Indeks SE Thailand turun 1,14\%, FTSE Malaysia -0,93\%, FTSE Strait Times $-1,67 \%$ dan indeks Topox anjlok hingga $-4,93 \%$. Begitu juga indeks Hang Seng Hong Kong yang -3,93\% dan Nikkei225 yang turun 5,40\%. Kepala Riset PT Universal Broker Indonesia Satrio Utomo mengatakan pelemahan IHSG sejak pagi tadi disebabkan oleh kekhawatiran pasar, termasuk pasar regional terhadap hasil pemilu Presiden Amerika Serikat. Menurut Beaulieu et al (2006), peristiwa politik berpengaruh kuat terhadap tingkat pengembalian dan perdagangan.

Banyak peristiwa yang dapat mempengaruhi harga saham di pasar begitu peristiwa itu terjadi (Samsul, 2006:274). Persitiwa politik memainkan peran penting dalam menjelaskan variasi kinerja pasar saham dan tingkat ketidakpastian di pasar saham (Tzachi, 2003). Suatu peristiwa seperti pemilihan umum presiden Amerika Serikat dimungkinkan dapat mempengaruhi aktivitas pasar modal. Meski peristiwa politik tidak memiliki hubungan langsung dengan pasar saham namun mereka dianggap salah satu faktor utama yang dapat mempengaruhi pasar saham (Nazir et al, 2014). Hal ini tercermin dari respon investor dalam menyerap informasi baik maupun buruk untuk mengambil suatu keputusan investasi yang diharapkan memberikan return yang sesuai kedepannya. Menurut Hartawan,dkk (2015) setiap return yang diterima sebagai imbalan dari saham yang ditanamkan 
adalah return realisasi, sedangkan return yang diharapkan diterima dimasa yang akan datang adalah return ekspetasi.

Tingkat risiko politik dan pengaruhnya terhadap investasi sangatlah penting untuk diukur sebelum melakukan investasi. Hal ini patut dipertimbangkan karena perubahan kebijakan akan berdampak besar terhadap sektor perekonomian suatu negara. Risiko politik umumnya memiliki keterkaitan dengan pemerintahan serta situasi politik dan keamanan suatu negara. Risiko politik merupakan salah satu faktor penting yang mempengaruhi operasi pasar keuangan suatu negara, bisa datang dalam berbagai bentuk seperti kudeta, pemilihan, atau perubahan rezim negara (Kabiru et al, 2015). Situasipolitik yang stabil mempunyai risiko investasiyang rendah dan risiko yang rendah mendorongpertumbuhan, investasi modal dan meningkatkan kinerja ekonomisecara keseluruhan(Bechtel, 2009). Jorion dan Geotzmann (1999) mengemukakan bahwa peristiwa politik memberi gangguan di transaksi pasar. Beberapa alasan pentingnya peristiwa politik yang dapat mempengaruhi kesejahteraan ekonomi antara lain untuk menentukan kebijakan jangka panjang, informasi yang langsung diperoleh karena banyak media yang meliput dan harapan para investor bagi calon yang terpilih dapat menguntungkan bagi investor. Menurut Beaulieu et al (2006), peristiwa politik berpengaruh kuat terhadap tingkat pengembalian dan perdagangan.

Volatilitas harga saham merupakan resiko yang harus diterima oleh investor dalam melakukan investasi di pasar modal. Volatilitas harga saham sendiri adalah besarnya jarak antara fluktuasi/naik turunnya harga saham atau 
valas. Volatilitas harga saham dapat memberi keuntungan bagi investor jika harga saham naik dengan mendapat capital gain.

Abnormal Return adalah selisih antara tingkat keuntungan sebenarnya dengan tingkat keuntungan yang diharapkan (Sularso, 2003). Abnormal return digunakan untuk mengukur reaksi pasar terhadap suatu kandungan informasi dalam pengumuman (Jogiyanto, 2009). Penelitian yang dilakukan Rahmawati dan Pandansari (2016) menunjukkan bahwa tak terdapat perbedaan rata-rata abnormal return sebelum dan sesudah perombakan (reshuffle) kabinet kerja Jokowi tahun 2015. Terpilihnya Donald Trump menjadi presiden Amerika Serikat diperkirakan memberi dampak yang cukup besar terhadap pasar modal di Indonesia, dikarenakan akan ada perubahan kebijakan yang diambil jika Donald Trump terpilih menjadi presiden utamanya kebijakan di bidang ekonomi.

Trading volume activity adalah alat yang dipergunakanuntuk melihat bagaimana pasar bereaksiterhadap adanya informasi di pasar modal dengan melihat pergerakantrading volume activity (Fama, 1991). Suatu surat berharga yang memiliki volume perdagangan yangtinggi, maka akanmenghasilkan return saham yang tinggi(Chordia et al.,2000). Penelitian yang dilakukan Gong et al, (2001) menyatakanvolume perdagangansecara signifikan mempengaruhireturn saham. Sementara penelitian Wahyudi (2004) menyatakandampak dari kenaikanharga BBM, adalah harga saham dan volume perdagangan saham akancenderung mengalami penurunan. Trading volume activity dipergunakan untuk melihat respon pasar terhadap kemenangan Donald Trump dalam pemilihan 
presiden Amerika Serikat dengan melihat pergerakan volume perdagangan di pasar modal.

Event study dipergunakan untuk melihat pengaruh dari berbagai peristiwa terhadap aktivitas ekonomi. Seperti penelitian yang dilakukan oleh Respati (2014) dalam penelitiannya menyatakan bahwa peristiwa yang diambil dalam penelitiannya memiliki kandungan informasi dan memberikan abnormal return kepada investor setelah event day. Penelitian ini bertujuan untuk memberikan suatu gambaran bahwa sebuah informasi politik dapat mempengaruhi harga saham. Hal ini terlihat dari bagaimana investor bereaksi terhadap informasi baru yang turun di pasar modal dan informasi tersebut diketahui secara umum sehingga adanya return saham dan volume perdagangan saham yang mencerminkan pergerakan saham para investor.

Abnormal return adalah selisih antara tingkat keuntungan yang sebenarnya dengan tingkat keuntungan yang diharapkan. Pada pasar yang efisien tidak akan ada pihak yang memungkinkan memperoleh abnormal return karena informasi dapat diserap dengan cepat oleh pasar untuk membentuk harga keseimbangan yang baru (Vahini, 2014). Rata-rata abnormal return dari seluruh jenis saham harian yang sedang dianalisisdisebut dengan average abnormal return. Average abnormal return dapat menunjukkan reaksi paling kuat, baik positif maupun negatif, dari keseluruhan jenis saham selama window period.

Penelitian Kemala (2017) menunjukan hasil bahwa tak terdapat abnormal return sebelum dan sesudah peristiwa publikasi Annual Report Award. Sedangkan penelitian Sirait, dkk (2012) menunjukan hasil bahwa terdapat perbedaan Avarage 
Abnormal Return yang signifikan sebelum dan setelah peristiwa pergantian menteri keuangan tahun 2010. Hasil serupa juga didapatkan Marisca (2013) yang menunjukan bahwa terdapat perbedaan yang signifikan Average Abnormal Return sebelum dan sesudah pengumuman kenaikan harga BBM.

Volume perdagangan saham merupakan suatu instrumen yang dapat digunakan untuk melihat reaksi pasar modal terhadap informasi yang diperdagangkan di pasar (Sutrisno, 2000). Saham yang aktif diperdagangkan merupakan indikasi aktivitas volume perdagangan saham yang besar. Hal ini dapat menurunkan tingkat bid-ask spread, dimana pedagang tidak akan lama menyimpan saham tersebut sebelum diperdagangkan.

Penelitian Suparsa (2014) menunjukan tidak terdapat perbedaan Trading Volume Activity sebelum dan sesudah kenaikanharga BBM. Sedangkan penelitian Neni (2004) menunjukan bahwa terdapat perbedaan rata-rata volume perdagangan saham pada periode sebelum dan sesudah peristiwa Pemilu Legislatif Indonesia tahun 2004. Hasil serupa juga didapatkan Wardhani (2013) yang menunjukan terdapat perbedaan yang tak signifikan rata-rata trading volume activity pada periode sebelum dan setelah peristiwa pemilihan Gubernur DKI Jakarta Putaran II 2012. Berdasarkan uraian tersebut maka hipotesis yang dirumuskan adalah:

$\mathrm{H}_{1}$ : Terdapat perbedaan rata-rata abnormal return sebelum dan sesudah pengumuman kemenangan Donald Trump menjadi Presiden Amerika Serikat.

$\mathrm{H}_{2}$ : $\quad$ Terdapat perbedaan rata-rata trading volume activity sebelum dan sesudah pengumuman kemenangan Donald Trump menjadi Presiden Amerika Serikat. 


\section{METODE PENELITIAN}

Penelitianini menggunakan metode kuantitatif yang bersifat event study atau studi peristiwa. Studi peristiwa merupakan studiyang mempelajari reaksi pasarterhadap suatuperistiwa (event) yang informasinya dipublikasikan sebagaisuatu pengumuman. Objek dalam penelitianini adalah abnormal return dan trading volume activity sebelum dan sesudah pengumuman kemenangan Donald Trump menjadi presiden Amerika Serikat pada perusahaan go public yang tercatat di Bursa Efek Indonesia.

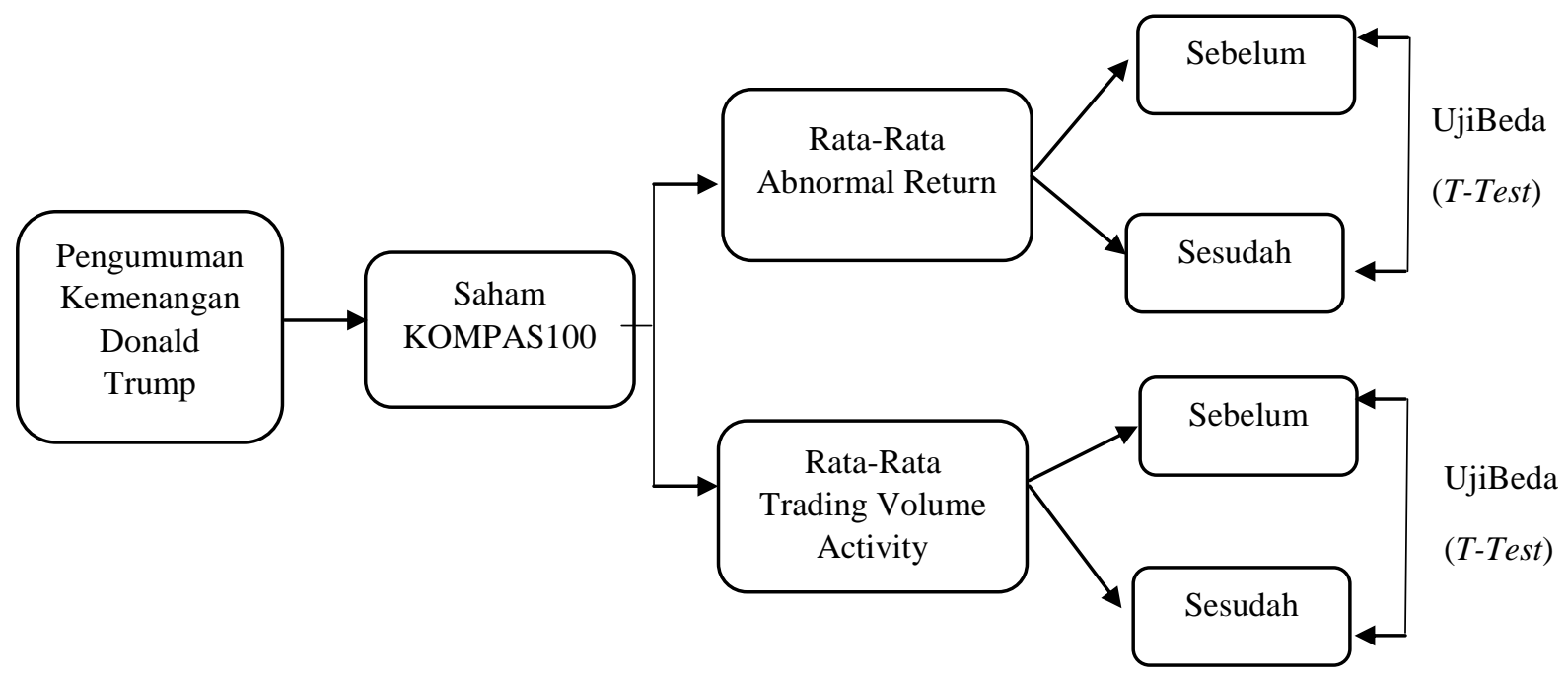

Gambar 1.

Desain Penelitian

Penelitian ini menggunakan data sekunder yang diperoleh dengan mengakses internet pada website yang tersedia. Penelitian dilakukan dengan mengakses website Bursa Efek Indonesia yaitu www.idx.co.id dan www.finance.yahoo.com. 
Adapun obyek pada penelitian ini yaitu abnormal return dan trading volume activity sebelum, ketika pengumuman dan sesudah pengumuman kemenangan Donald Trump menjadi Presiden Amerika Serikat yang diketahui dari harga saham, volume perdagangan saham dan return pada saat event period.

Variabel yang digunakan dalam penelitian iniadalah variabel tunggal. Adapun pengertian variabel tunggal adalah himpunan sejumlah gejala yang memiliki berbagai aspek atau kondisi di dalamnya yang berfungsi mendominasi dalam kondisiatau masalah tanpa dihubungkan dengan lainnya (Hadari Nawawi, 1996: 58). Berdasarkan pemaparan diatas, variabel tunggal dalam penelitian ini yaitu pengumuman kemenangan Donald Trump menjadi Presiden Amerika Serikat.

Penelitian ini definisi operasional variabel adalah abnormal return dan trading volume activity. Pengujian abnormal return dalam penelitian inimenggunakanpengukuranmarket adjusted model, karena pengukuran model ini beranggapan bahwa penduga terbaik untuk mengestimasi returnsuatu sekuritas adalah return indeks pasar padasaat tersebut. Jika menggunakanmodel market adjusted model ini, maka tidak perlu menggunakan periode estimasi untuk membentuk model estimasi, karena return sekuritas yang diestimasi sama dengan return indeks pasar. Sedangkan, trading volume activity merupakan instrumentyang bisa digunakan untuk melihat reaksi pasar modal terhadap informasimelalui parameter perubahan volume perdagangan saham (Fatmawati dan Asri, 1999). 
Penelitian ini mengasumsikan pasar modal di Indonesia sudah efisien dalam bentuk setengah kuat, ini dikarenakan pasar modal Indonesia masih berkembang. Penelitian ini menggunakan penelitian selama 15 hari yaitu 7 hari sebelum pengumuman kemenangan Donald Trump menjadi Presiden Amerika Serikat (H-7), 1 hari merupakan tanggal pengumuman kemenangan Donald Trump menjadi Presiden Amerika Serikat (event period) dan 7 hari setelah pengumuman kemenangan Donald Trump menjadi Presiden Amerika Serikat $(\mathrm{H}+7)$.

Actual Return dapat dihitung dengan rumus sebagai berikut (Hartono, 2014:610) :

$$
\mathrm{R}_{\mathrm{it}}=\frac{\mathrm{P}_{\mathrm{it}} \mathrm{P}_{\mathrm{it}-1}}{\mathrm{P}_{\mathrm{it}-1}}
$$

Keterangan :

$\mathrm{R}_{\mathrm{it}} \quad=$ keuntungan saham i pada periode $\mathrm{t}$

$\mathrm{P}_{\mathrm{t}} \quad=$ harga saham pada periode $\mathrm{t}$

$\mathrm{P}_{\mathrm{t}-1} \quad$ = harga saham pada periode $\mathrm{t}-1$

Return ekspetasian dirumuskan sebagai berikut (Hartono, 2014:621) :

$$
\mathrm{E}\left(\mathrm{R}_{\mathrm{it}}\right)=\mathrm{R}_{\mathrm{Mit}}
$$

Keterangan :

$$
\begin{array}{ll}
\mathrm{E}\left(\mathrm{R}_{\mathrm{it}}\right) & =\text { return } \text { ekspetasi } \\
\mathrm{R}_{\text {Mit }} & =\text { return pasar pada periode } \mathrm{t}
\end{array}
$$

Adapun rumus yang digunakan dalam menghitung abnormal return adalah sebagai berikut (Hartono, 2014:609) :

$$
\mathrm{AR}_{\mathrm{it}}=\mathrm{R}_{\mathrm{it}}-\mathrm{E}\left[\mathrm{R}_{\mathrm{it}}\right]
$$


Keterangan :

$\mathrm{AR}_{\mathrm{it}} \quad=$ abnormal return saham ke-i pada periode peristiwa ke-t

$\mathrm{R}_{\mathrm{it}} \quad=$ actual return yang terjadiuntuk saham ke-i pada periodeperistiwa ke-t

$\mathrm{E}\left[\mathrm{R}_{\mathrm{it}}\right] \quad=$ expected return saham ke-inuntuk periode peristiwa ke-t

Adapun rumus yang dipergunakan untuk menghitung trading volume activity sebagai berikut:

$$
\mathrm{TVA}_{\mathrm{it}}=\frac{\sum \text { Saham i ditransaksikan } \mathrm{t}}{\sum \text { Saham i beredar } \mathrm{t}}
$$

Rata-Rata Abnormal Return dipergunakan sebagai perbandingan untuk melihat reaksi pasar akan suatu peristiwa. Adapun rumus yang dipergunakan untuk menghitung rata-rata abnormal return sebagai berikut (Jogiyanto, 2009:569):

$$
\begin{aligned}
& \overline{\mathrm{AR}} \text { sebelum }=\frac{\sum_{\mathrm{t}=-7}^{\mathrm{t}=-1} \mathrm{AR} \text { sebelum }}{\mathrm{n}} \\
& \overline{\mathrm{AR}} \text { sesudah }=\frac{\sum_{\mathrm{t}=+7}^{\mathrm{t}=+1} \mathrm{AR} \text { sesudah }}{\mathrm{n}}
\end{aligned}
$$

Keterangan :

$$
\begin{array}{ll}
\overline{A R} \text { sebelum } & =\text { rata-rata abnormal return sebelum peristiwa } \\
A R \text { sebelum } & =\text { abnormal return sebelum peristiwa } \\
\overline{A R} \text { sesudah } & =\text { rata-rata abnormal return sesudah peristiwa } \\
\text { ARsesudah } & =\text { abnormal return sesudah peristiwa } \\
\mathrm{n} & =\text { jumlah sampel }
\end{array}
$$

Adapun rumus yang dipergunakan untuk menghitung rata-rata trading volume activity sebagai berikut:

$\overline{\mathrm{TVA}}$ sebelum $=\frac{\sum_{\mathrm{t}=-7}^{\mathrm{t}=-1} \mathrm{TVA} \text { sebelum }}{\mathrm{n}}$ 


$$
\overline{\mathrm{TVA}} \text { sesudah }=\frac{\sum_{\mathrm{t}=+7}^{\mathrm{t}=+1} \mathrm{TVA} \text { sesudah }}{\mathrm{n}}
$$

\section{Keterangan :}

$\overline{T V A}$ sebelum $=$ rata-rata trading volume activity sebelum peristiwa

TVA sebelum $=$ trading volume activity sebelum peristiwa

$\overline{T V A}$ sesudah = rata-rata trading volume activity sesudah peristiwa

TVA sesudah $=$ trading volume activity sesudah peristiwa

$\mathrm{n} \quad=$ jumlah sampel

Data kuantitatif merupakan data yang berupa angka-angka atau data kualitatif yang diangkakan (Sugiyono, 2013:14). Data kuantitatif dalam penelitian ini yaitu angka-angka yang tersaji di dalam laporan keuangan perusahaanperusahaan yang terdaftar di Bursa Efek Indonesia sebelum dan sesudah pengumuman kemenangan Donald Trump menjadi Presiden Amerika Serikat yaitu dari tanggal 31 Oktober 2016 sampai 18 November 2016.

Penelitian ini menggunakan data sekunder dalam bentuk-bentuk seperti angka, grafik, tabel, gambar, diagram dan lain-lain sehingga data tersebut lebih informatif bagi pihak yang membutuhkan. Data sekunder dalam penelitian ini adalah harga penutupan saham harianserta data jumlah saham yang diperdagangkan dan jumlah sahamyang beredar masing-masing sekuritas pada saham yang tergolong indeks KOMPAS100 selama lima belas hari sebelum dan sesudah tanggal pengumuman kemenangan Donald Trump menjadi presiden Amerika Serikat yang diperoleh dari website Bursa Efek Indonesia (www.idx.co.id) dan www.yahoofinance.com. 
Menurut Sugiyono (2013:115) populasi adalah wilayah generalisasi yang terdiri atas obyek atau subyek yang mempunyai kualitas dan karakteristik tertentu yang ditetapkan oleh peneliti untuk dipelajari dan kemudian ditarik kesimpulannya. Jadi berdasarkan penjelasan tersebut yang menjadi populasi dalam penelitian ini adalah seluruh perusahaan tergolong KOMPAS100 yang terdaftar di Bursa Efek Indonesia yang berjumlah 100 perusahaan.

Sampel adalah bagian dari jumlah dan karakteristik yang dimiliki oleh populasi (Sugiyono, 2013:116). Pengambilan sampel berarti mengambil sebagian saja dari populasi untuk menggambarkan populasi secara keseluruhan atau representatif. Sampel dalam penelitian ini terdiri dari 94 perusahaan yang dipilih menggunakan metode purposive sampling berdasarkan kriteria yang sudah ditentukan dengan pertimbangan perusahaan melakukan aktivitas perdagangan saham dan perusahaan tidak melakukan corporate action. Adapun pembagian perusahaan tersebut adalah sebagaiberikut:

Tabel 1.

Kriteria Penentuan Sampel

\begin{tabular}{clc}
\hline No & \multicolumn{1}{c}{ Keterangan } & Jumlah Perusahaan \\
\hline 1 & $\begin{array}{l}\text { Jumlah seluruh perusahaan } \\
\text { Perusahaan yang tidak melakukan aktivitas } \\
\text { perdagangan saham saat } \text { event period: } \\
\text { Perusahaan yang melakukan corporate action: }\end{array}$ & 100 Perusahaan \\
1 & $\begin{array}{l}\text { Pembagian deviden } \\
2\end{array}$ & 2 Perusahaan \\
\hline & \multicolumn{1}{c}{ Total Sampel } & 1 Perusahaan \\
& & 3 Perusahaan \\
\hline Sumber: Bursa Efek Indonesia, 2017
\end{tabular}

Teknik analisis data dalam penelitian ini dengan menggunakan statistik deskriptif, uji normalitas dan uji hipotesis menggunakan uji Wilcoxon signed rank t-test 


\section{HASIL DAN PEMBAHASAN}

Perhitungan rata-rata abnormal return diperoleh melalui data-data harga saham yang dihitung dengan rumus dan dirata-ratakan untuk perusahaan-perusahaan yang dijadikan sampel selama event period. Pada Tabel 2. dan Gambar 2. disajikan hasil perhitungan rata-rata abnormal return selama periode peristiwa.

Tabel 2.

Hasil Perhitungan Rata-Rata Abnormal Returndi Sekitar Peristiwa

\begin{tabular}{|c|c|c|}
\hline Tanggal & Periode & Rata-Rata Abnormal Return \\
\hline 31 Oktober 2017 & $t-7$ & 0,002430 \\
\hline 01 November 2017 & $t-6$ & $-0,000508$ \\
\hline 02 November 2017 & $\mathrm{t}-5$ & $-0,004669$ \\
\hline 03 November 2017 & $\mathrm{t}-4$ & 0,004113 \\
\hline 04 November 2017 & $t-3$ & 0,003970 \\
\hline 07 November 2017 & $\mathrm{t}-2$ & 0,001261 \\
\hline 08 November 2017 & $\mathrm{t}-1$ & $-0,008198$ \\
\hline 09 November 2017 & $\mathrm{t}=0$ & - \\
\hline 10 November 2017 & $\mathrm{t}+1$ & 0,007427 \\
\hline 11 November 2017 & $t+2$ & 0,012959 \\
\hline 14 November 2017 & $t+3$ & $-0,000274$ \\
\hline 15 November 2017 & $\mathrm{t}+4$ & $-0,009843$ \\
\hline 16 November 2017 & $t+5$ & 0,003407 \\
\hline 17 November 2017 & $\mathrm{t}+6$ & $-0,000516$ \\
\hline 18 November 2017 & $\mathrm{t}+7$ & $-0,002860$ \\
\hline
\end{tabular}




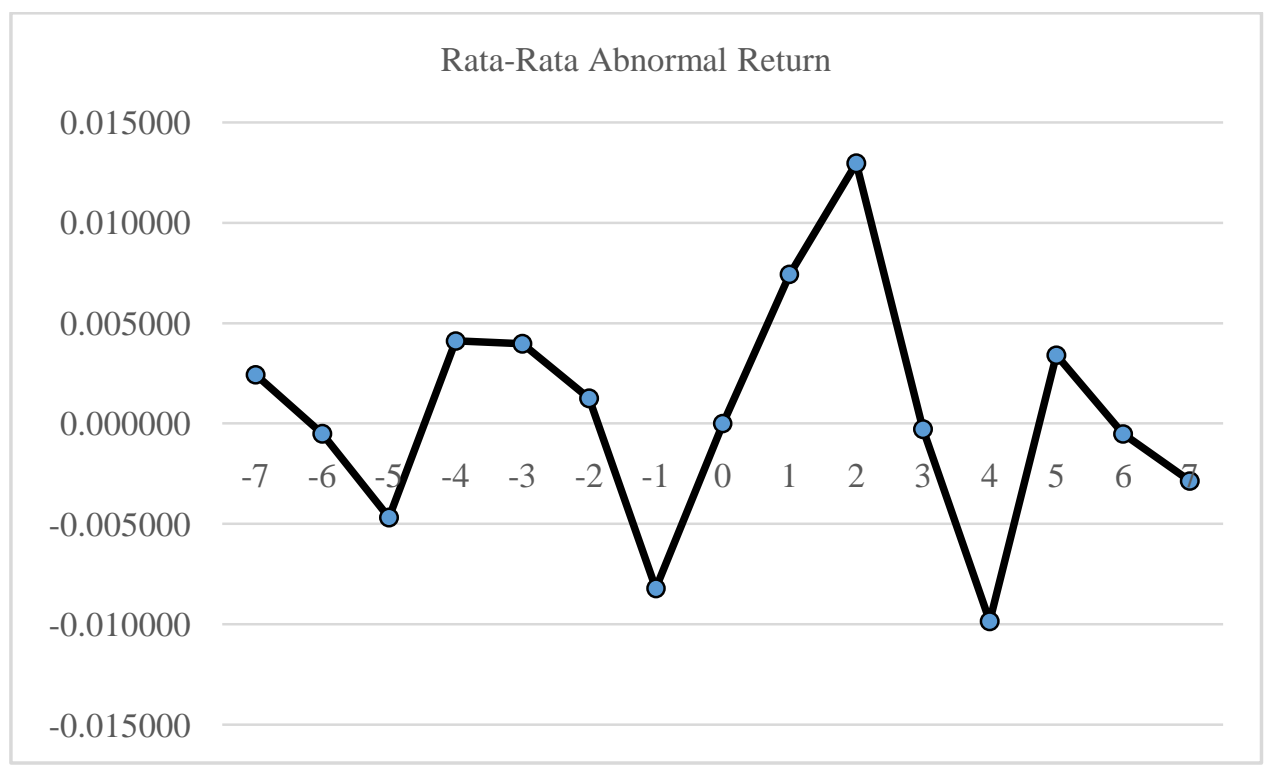

Gambar 2.

Sumber: Data diolah, 2017

\section{Grafik Pergerakkan Rata-Rata Abnormal Return}

Berdasarkan hasil perhitungan pada Tabel 2. dan Gambar 2, dapat diperhatikan bahwa pergerakkan nilai rata-rata abnormal return cukup fluktuatif selama 15 hari periode peristiwa. Pada periode sebelum pengumuman kemenangan Donald Trump menjadi presiden Amerika Serikat, pergerakan ratarata abnormal returnmenurun,ini dapat dilihat pada periode t-6 mengalami penurunan dan meningkat sejenak sehari setelahnya dan kembali mengalami penurunan pada periode $\mathrm{t}-4$ hingga periode $\mathrm{t}-1$. Selanjutnya, periode sehari setelah pengumuman kemenangan Donald Trump menjadi presiden Amerika Serikat, rata-rata abnormal return masih mengalami peningkatan hingga periode $\mathrm{t}+2$ dan kembali mengalami penurunan pada periode $t+3$ sampai $t+4$ dan mencapai nilai terendah yaitu sebesar -0,009843. Namun sehari setelahnya mengalami peningkatan sejenak dan kembali mengalami penurunan pada periode $t+6$ hingga 
t+7 atau 7 hari setelah pengumuman kemenangan Donald Trump menjadi presiden Amerika Serikat dengan nilai -0,002860.

Tabel 3.

Hasil PerhitunganRata-Rata Trading Volume Activity di Sekitar Peristiwa

\begin{tabular}{|c|c|c|}
\hline Tanggal & Periode & Rata-Rata Trading Volume Activity \\
\hline 31 Oktober 2017 & $\mathrm{t}-7$ & 0,002885 \\
\hline 01 November 2017 & $\mathrm{t}-6$ & 0,002587 \\
\hline 02 November 2017 & $\mathrm{t}-5$ & 0,003371 \\
\hline 03 November 2017 & $\mathrm{t}-4$ & 0,003123 \\
\hline 04 November 2017 & $\mathrm{t}-3$ & 0,002950 \\
\hline 07 November 2017 & $\mathrm{t}-2$ & 0,002913 \\
\hline 08 November 2017 & $\mathrm{t}-1$ & 0,003068 \\
\hline 09 November 2017 & $\mathrm{t}=0$ & - \\
\hline 10 November 2017 & $\mathrm{t}+1$ & 0,003163 \\
\hline 11 November 2017 & $\mathrm{t}+2$ & 0,003778 \\
\hline 14 November 2017 & $t+3$ & 0,003363 \\
\hline 15 November 2017 & $\mathrm{t}+4$ & 0,003144 \\
\hline 16 November 2017 & $\mathrm{t}+5$ & 0,003063 \\
\hline 17 November 2017 & $\mathrm{t}+6$ & 0,002170 \\
\hline 18 November 2017 & $\mathrm{t}+7$ & 0,001741 \\
\hline
\end{tabular}




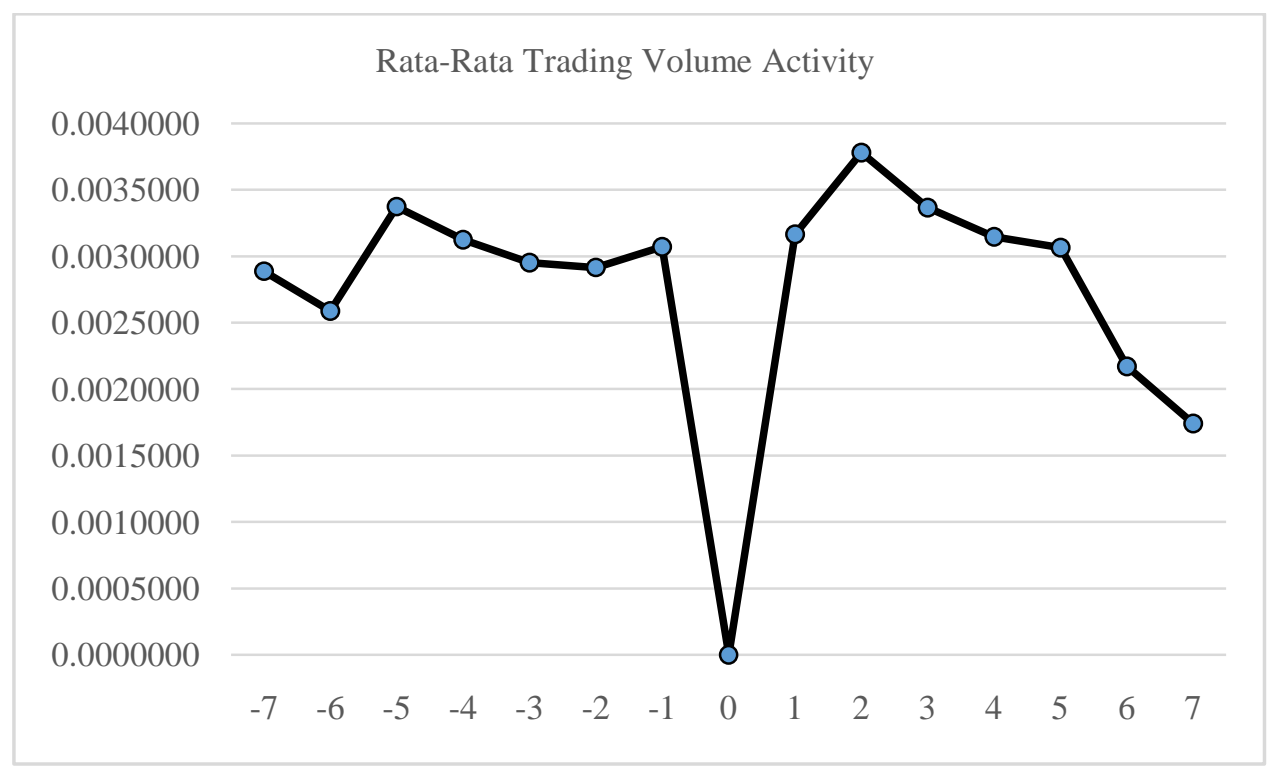

Gambar 3.

Grafik Pergerakkan Rata-Rata Trading Volume Activity Sumber: Data diolah, 2017

Berdasarkan hasil perhitungan pada Tabel 3. dan Gambar 3, dapat diperhatikan bahwa pergerakan nilai rata-rata trading volume activity cukup fluktuatif selama 15 hari periode peristiwa. Pada periode sebelum pengumuman kemenangan Donald Trump menjadi presiden Amerika Serikat, pergerakan ratarata trading volume activity cenderung menurun, hal ini dibuktikan dari nilai ratarata trading volume activity pada periode t-6 mengalami penurunan dan meningkat kembali sejenak pada periode t-5 dan kembali mengalami penurunan pada periode $\mathrm{t}-4$ hingga $\mathrm{t}-2$. Namun, pada periode sehari sebelum pengumuman kemenangan Donald Trump menjadi presiden Amerika Serikat nilai rata-rata trading volume activity mengalami peningkatan sejenak dengan nilai 0,003068. Selanjutnya, sehari setelah peristiwa, rata-rata trading volume activity mengalami peningkatan hingga $t+2$ dan kembali mengalami penurunan pada periode $t+3$ 
hingga $t+7$ atau 7 hari setelah pengumuman kemenangan Donald Trump menjadi presiden Amerika Serikat dan mencapai nilai terendah yaitu sebesar 0,001741.

Tabel 4.

Hasil Analisis Deskriptif Data Rata-Rata Abnormal Return

\begin{tabular}{cccccc}
\hline & N & Minimum & Maximum & Mean & Std. Deviation \\
\hline AAR Sebelum & 94 & $-0,021291$ & 0,072587 & $-0,000228$ & 0,011553 \\
AAR Sesudah & 94 & $-0,023034$ & 0,030274 & 0,001471 & 0,008763 \\
\hline
\end{tabular}

Nilai terendah rata-rata abnormal return sebelum pengumuman kemenangan Donald Trump menjadi presiden Amerika Serikat diperoleh oleh perusahaan Summarecon Agung Tbk. sebesar -0,021291 sementara nilai tertinggi diperoleh oleh perusahaan Bumi Resources Tbk. sebesar 0,072587. Nilai mean rata-rata abnormal return sebelum pengumuman kemenangan Donald Trump menjadi presiden Amerika Serikat bernilai negatif sebesar -0,000228dan standar deviasinya sebesar 0,011553 .

Nilai terendah rata-rata abnormal return sesudah pengumuman kemenangan Donald Trump menjadi presiden Amerika Serikat diperoleh oleh perusahaan Global Mediacom Tbk. sebesar -0,023034 sementara nilai tertinggi diperoleh oleh Semen Baturaja (Persero) Tbk. sebesar 0,030274. Nilai mean ratarata abnormal return sesudah pengumuman kemenangan Donald Trump menjadi presiden Amerika Serikat bernilai positif sebesar 0,001471 dan standar deviasinya sebesar 0,008763 .

Nilai rata-rata abnormal return sebelum dan sesudah pengumuman kemenangan Donald Trump menjadi presiden Amerika Serikat memiliki 
perbedaan selisih yang kecil yaitu sebesar 0,001700, sehingga dapat disimpulkan terdapat perbedaan rata-rata abnormal return sebelum dan sesudah pengumuman kemenangan Donald Trump menjadi presiden Amerika Serikat.

Tabel 5.

Hasil Analisis Deskriptif Rata-Rata Trading Volume Activity

\begin{tabular}{lccccc}
\hline & N & Minimum & Maximum & Mean & Std. Deviation \\
\hline ATVA Sebelum & 94 & 0,000056 & 0,058894 & 0,002985 & 0,006848 \\
ATVA Sesudah & 94 & 0,000108 & 0,045870 & 0,002917 & 0,005340 \\
\hline
\end{tabular}

Sumber: data diolah, 2017

Tabel 5.menjelaskan nilai terendah, nilai tertinggi, rata-rata dan standar deviasi dari rata-rata trading volume activity sebelum dan sesudah pengumuman kemenangan Donald Trump menjadi presiden Amerika Serikat masing-masing perusahaan selama lima belas hari pengamatan yaitu dari 31 Oktober 2016 sampai 18 November 2016. Nilai terendah rata-rata trading volume activity sebelum pengumuman kemenangan Donald Trump menjadi presiden Amerika Serikat diperoleh oleh perusahaan Indosat Tbk. sebesar 0,000056 sementara nilai tertinggi diperoleh oleh perusahaan Bumi Resources Tbk. sebesar 0,058894. Nilai mean rata-rata trading volume activity sebelum pengumuman kemenangan Donald Trump menjadi presiden Amerika Serikat bernilai positif sebesar 0,002985 dan standar deviasinya sebesar 0,006848 .

Nilai terendah rata-rata trading volume activity sesudah pengumuman kemenangan Donald Trump menjadi presiden Amerika Serikat diperoleh oleh perusahaan Bank Pan Indonesia Tbk. sebesar 0,000108 dan nilai tertingginya diperoleh oleh perusahaan Bumi Resources Tbk. sebesar 0,045870. Nilai mean rata-rata trading volume activity sesudah pengumuman kemenangan Donald 
Trump menjadi presiden Amerika Serikat bernilai positif sebesar 0,002917 dan standar deviasinya sebesar 0,005340 . Nilai mean rata-rata trading volume activity sebelum dan sesudah pengumuman kemenangan Donald Trump menjadi presiden Amerika Serikat sama-sama memiliki persebaran data yang kecenderungannya ke arah maximum. Dari nilai mean rata-rata trading volume activity bisa dilihat volume perdagangan saham sebelum pengumuman kemenangan Donald Trump lebih tinggi dari rata-rata volume perdagangan saham sesudah pengumuman kemenangan Donald Trump.

Nilai rata-rata trading volume activity sebelum dan sesudah pengumuman kemenangan Donald Trump menjadi presiden Amerika Serikat memiliki perbedaan selisih yang sangat kecil sebesar 0,000068 sehingga dapat disimpulkan terdapat perbedaan rata-rata trading volume activity sebelum dan sesudah pengumuman kemenangan Donald Trump menjadi presiden Amerika Serikat.

Tabel 6.

Hasil UjiNormalitas Rata-Rata Abnormal Return

\begin{tabular}{llrr}
\hline & & AAR Sebelum & AAR Sesudah \\
\hline $\mathrm{N}$ & & 94 & 94 \\
Normal Parameters $^{\text {a,b }}$ & Mean & $-0,000228$ & 0,001471 \\
& Std. Deviation & 0,011553 & 0,008763 \\
& Absolute & 0,209 & 0,059 \\
Most Extreme Differences & Positive & 0,209 & 0,059 \\
& Negative & $-0,146$ & $-0,055$ \\
Kolmogorov-Smirnov Z & & 2,025 & 0,568 \\
Asymp. Sig. (2-tailed) & & 0,001 & 0,904 \\
\hline Sumber: data diolah, 2017 & & &
\end{tabular}

Tabel 6. Menampilkan hasil uji normalitas rata-rata abnormal return sebelum dan sesudah dari 94 perusahaan menggunakan Kolmogrov-Smirnov Test. 
Hasil pengujian pada tabel6.menunjukan nilai Sig. sebelum pengumuman kemenangan Donald Trump menjadi presiden Amerika Serikat <alpha yaitu sebesar 0,001 dan nilai Sig. sesudah pengumuman kemenangan Donald Trump menjadi presiden Amerika Serikat >alpha yaitu sebesar 0,904. Pada hasil pengujian nilai Sig. sebelum dan sesudah pengumuman kemenangan Donald Trump menjadi presiden Amerika Serikat salah satu data <alpha maka dapat ditarik kesimpulan bahwa data rata - rata abnormal return tidak berdistribusi normal. Data yang tidak berdistribusi normal diuji dengan menggunakan uji Wilcoxon Signed Ranks Test.

Tabel 7.

Hasil UjiNormalitas Rata-Rata Trading Volume Activity

\begin{tabular}{|c|c|c|c|}
\hline & & ATVA Sebelum & ATVA Sesudah \\
\hline $\mathrm{N}$ & & 94 & 94 \\
\hline \multirow{2}{*}{ Normal Parameters ${ }^{\mathrm{a}, \mathrm{b}}$} & Mean & 0,002985 & 0,002917 \\
\hline & Std. Deviation & 0,006848 & 0,005340 \\
\hline \multirow{3}{*}{ Most Extreme Differences } & Absolute & 0,334 & 0,299 \\
\hline & Positive & 0,291 & 0,249 \\
\hline & Negative & $-0,334$ & $-0,299$ \\
\hline Kolmogorov-Smirnov Z & & 3,242 & 2,904 \\
\hline Asymp. Sig. (2-tailed) & & 0,000 & 0,000 \\
\hline
\end{tabular}

Tabel 7. menampilkan hasil uji normalitas rata-rata trading volume activity sebelum dan sesudah 94 perusahaan menggunakan Kolmogrov-Smirnov Test. Hasil pengujian pada tabel 7.menunjukkan nilai Sig. sebelum pengumuman kemenangan Donald Trump menjadi presiden Amerika Serikat <alpha yaitu sebesar 0,000 dan nilai Sig. sesudah pengumuman kemenangan Donald Trump menjadi presiden Amerika Serikat <alpha yaitu sebesar 0,000. Pada hasil pengujian nilai Sig. sebelum dan sesudah pengumuman kemenangan Donald 
Trump menjadi presiden Amerika Serikat sama-sama <alpha maka dapat ditarik kesimpulan bahwa data rata-rata trading volume activity tidak berdistribusi normal. Data yang tidak berdistribusi normal diuji dengan menggunakan uji wilcoxon signed ranks test.

Tabel 8.

Hasil Uji Wilcoxon Signed Ranks Test terhadap Perbedaan Rata-Rata Abnormal Return

\begin{tabular}{llrrr}
\hline & N & Mean Rank & Sum of Ranks \\
\hline \multirow{3}{*}{ AAR Sesudah - AAR } & Negative Ranks & $28^{\mathrm{a}}$ & 51,54 & 1443,00 \\
Sebelum & Positive Ranks & $66^{\mathrm{b}}$ & 45,79 & 3022,00 \\
& Ties & $0^{\mathrm{c}}$ & & \\
& Total & 94 & \\
\hline
\end{tabular}

\begin{tabular}{lr}
\hline \multicolumn{2}{c}{ Test Statistics $^{\text {a }}$} \\
\hline & AAR Sesudah - \\
& AAR Sebelum \\
\hline $\mathrm{Z}$ & $-2,977^{\mathrm{b}}$ \\
Asymp. Sig. (2-tailed) & 0,003 \\
\hline Sumber: data diolah, 2017
\end{tabular}

Berdasarkan hasil pengolahan yang diperlihatkan pada Tabel 8.menunjukkanhasil pengujian Sig. (2-tailed) $0.003<0.05$. Hasil pengujian menggunakan SPSS ini menunjukkan terdapat perbedaan rata-rata abnormal return yang signifikan sebelum dan sesudah pengumuman kemenangan Donald Trump menjadi presiden Amerika Serikat selama event period. Hasil pengujian juga menyimpulkanbahwa menolak $\mathrm{H}_{0}$ dan menerima $\mathrm{H}_{1}$. 
Tabel 9.

Hasil Uji Wilcoxon Signed Ranks Test terhadap Perbedaan Rata-Rata Trading Volume Activity

\begin{tabular}{llrrr}
\hline & & N & Mean Rank & Sum of Ranks \\
\hline & Negative Ranks & $36^{\mathrm{a}}$ & 45,58 & 1641,00 \\
ATVA Sesudah - ATVA & Positive Ranks & $58^{\mathrm{b}}$ & 48,69 & 2824,00 \\
Sebelum & Ties & $0^{\mathrm{c}}$ & & \\
& Total & 94 & & \\
\hline
\end{tabular}

\begin{tabular}{lr}
\hline \multicolumn{2}{c}{ Test Statistics $^{\mathrm{a}}$} \\
\hline & $\begin{array}{c}\text { ATVA Sesudah } \\
\text { - ATVA }\end{array}$ \\
& Sebelum \\
\hline $\mathrm{Z}$ & $-2,231^{\mathrm{b}}$ \\
Asymp. Sig. (2-tailed) & 0,026 \\
\hline Sumber: data diolah, 2017 &
\end{tabular}

Secara keseluruhan Tabel 9.menunjukkan probabilitas dari pengumuman kemenangan Donald Trump menjadi presiden Amerika Serikat disimpulkan memiliki kaitan dengan aktivitas volume perdagangan saham yang terlihat darinilai signifikan yang lebih dari kecil dari alpha. Hal ini disebabkan karena pengumuman kemenangan Donald Trump menjadi presiden Amerika Serikat menjadi salah satu pertimbangan pengambilan keputusan oleh investor.

Hasil penelitian menunjukkan bahwa terdapat perbedaan rata-rata abnormal return sebelum dan sesudah pengumuman kemenangan Donald Trump menjadi presiden Amerika Serikat. Hal ini dapat disimpulkan bahwa kemungkinan informasi politik seperti pengumuman kemenangan Donald Trump menjadi presiden Amerika Serikat mempunyai kandungan informasi yang cukup untuk membuat pasar bereaksi dan dapat mempengaruhi preferensi investor dalam 
pembuatan keputusan investasinya, sehingga pasar secara keseluruhan mengantisipasi informasi tersebut yang tercermin dari adanya perbedaan rata-rata abnormal return yang diperoleh pada saat 7 hari sebelum hingga 7 hari sesudah pengumuman kemenangan Donald Trump menjadi presiden Amerika Serikat.

Hasil penelitian memperlihatkan bahwa terdapat perbedaan rata-rata trading volume activity sebelum dan sesudah pengumuman kemenangan Donald Trump menjadi presiden Amerika Serikat. Hal ini menunjukan kandungan informasi pada peristiwa tersebut cukup kuat untuk membuat pasar bereaksi.

\section{SIMPULAN}

Kesimpulan yang dapat diambil berdasarkan nilai hasil analisis data, dapat disimpulkan bahwa terdapat perbedaan rata-rata abnormal return dan rata-rata trading volume activity sebelum dan sesudah pengumuman kemenangan Donald Trump menjadi presiden Amerika Serikat. Hal ini menunjukkan terdapat kandungan informasi pada peristiwa pengumuman kemenangan Donald Trump menjadi presiden Amerika Serikat membuat pasar bereaksi.

Berdasarkan pembahasan penelitian maka adapun saran yang ingin disampaikan lewat hasil penelitian yaitu bagi investor sebaiknya lebih berhati-hati dalam melakukan investasi ketika terjadi peristiwa-peristiwa politik baik di dalam maupun luar negeri dan untuk peneliti-peneliti selanjutnya bisa melakukan pengamatan di seluruh perusahaan go public maupun pada masing-masing sektor yang ada di Bursa Efek Indonesia. Selain itu peneliti selanjutnya dapat menggunakan variabel security return variability dan trading frecuency. Peneliti 
selanjutnyajuga bisa menggunakan model perhitungan abnormal return lainnya seperti mean adjusted model atau market model sebagai bahanpembanding.

\section{REFERENSI}

Adnyani, Ketut Sonya dan I. G. A. M. Asri Dwija Putri. 2014. Reaksi Pasar Terhadap Pengumuman Reverse Split Pada Perusahaan Go Public di Indonesia. E-Jurnal Akuntansi Universitas Udayana. 7(2) h:145-152

Aly, H., Mehdian S., and Perry M. J. 2004. An analysis of the day of the week effects in the Egyptian stock market. International journal of business, 9(3). Pp:113-137

Anoraga, Pandji dan Piji Pakarti. 2003. Pengantar Pasar Modal. Jakarta: Rineka Cipta

Arikunto. 1989. Prosedur Penelitian Suatu Pendekatan Praktis. Bina Aksara. Jakarta. Hadari Nawawi. 1996. Op. Cit.

Aryasa, I. P. G. Chandra Artha dan I. G. N. Agung Suaryana. 2017. Reaksi Pasar Sebelum dan Sesudah Pengumuman Right Issue. E-Jurnal Akuntansi Universitas Udayana. 18(2). h:1426-1454

Baker, M. and Wurgler J. 2006. Investors Sentiment and the Cross-Section of Stock Returns. Journal of Finance. 61. Pp:1-66

Basdas, Ulkem and Adil Oran. 2014. Event Studies in Turkey. Borsa-Istanbul Journal. Pp:167-188

Beaulieu, M.C., Cosset J.C. and Essaddam N. 2006. Political uncertainty and stock market returns: evidence from the 1995 Quebec referendum. The Canadian Journal of Economics (Revue canadienne dOEconomique). 39(2). Pp:621-641

Bechtel, M.M. 2009. The political sources of systematic investment risk: lessons from a consensus democracy. The Journal of Politics. 71(2). Pp:661-677

Brigham, Eugene F., and Michael C. Ehrhard. 2011. Financial Management Theory and Practice 13th edition.

Brown, S dan J. Warner. 1985. Using Daily Return, Journal of Financial Economics, Vol.21 a61-193 
Brunner, Martin. 2009. Does Politics Matter? The Influence of elections and Government Formation in the Netherlands on the Amsterdam Exchage Index. Acta Politica. 44(2), p:150-170

Chordia, Tarun. Bhaskaran Swaminathan. 2000. Trading Volume and Cross Autocorrelations in Stock Returns. The Journal of Finance. Volume55, Issue 2. April 2000. Pages 913-935

Fama, EugeneF. 1991. EfficientCapital MarketII. Journal Of Finance. Desember. 66(5), pp:1-21

Fatmawati, S. dan Marwan Asri (1999),"Pengaruh Stock Split terhadap Likuiditas Saham yang Diukur dengan Besarnya Bid-Ask Spread di Bursa Efek Jakarta",Jurnal Ekonomi dan Bisnis Indonesia,Vol. 14, No. 4.

Frankel, R. and Lee C. M. 1998. Accounting valuation, market expectation, and cross sectional stock returns. Journal of Accounting and Economics, 25(3). Pp:283-319

Ghozali, H. Imam. 2016. Aplikasi Analisis Multivariate dengan Program IBM SPSS 23. Edisi kedelapan. Semarang: Badan Penerbit Universitas Diponegoro

Gong Meng Chen, Michael Firth and Oliver M. Rui. 2001. The Dynamic Relation Between Stock Return, Trading Volume and Volatility. The Financial Review. pp:153-174.

Hadari Nawawi. 1996. Penelitian Terapan. Yogyakarta: Gajah Mada University Pers. h:58

Hartawan, I Made; Adiputra, I Made Pradana; Darmawan, Nyoman Ari Surya. 2015. Analisis Perubahan Volume Perdagangan Saham dan Abnormal Return Sebelum dan Sesudah Pemilu Legislatif 9 April 2014 (Event Study pada Sektor-Sektor Industri di Bursa Efek Indonesia). e-Journal S1 Ak Universitas Pendidikan Ganesha Jurusan Akuntansi Program S1 (Volume 3 No. 1 Tahun 2015)

Hartono, Jogiyanto. 2014. Teori Portofolio dan Analisis Investasi, Edisi Kedelapan. Yogyakarta: BPFE

Hengky, Anastasian dan Memarista. 2014. Perbedaan Average Abnormal Return, Average Trading Volume Activity Sebelum dan Sesudah Pemilu di Indonesia.Jurnal Finesta, 2(1), h:114-118.

Husnan, Suad. 1996. Teori Portofolio Dan Analisis Sekuritas. UPP AMP YKPN Yogyakarta 
Ikatan Akuntan Indonesia .2007 .Standar Akuntansi Keuangan . Edisi 2007. Penerbit : Salemba Empat . Jakarta .

Jogiyanto, H.M. 2009. Teori Portofolio dan Analisis Investasi. Yogyakarta: BPFE

Jorion, P. and Geotzmann,W.N. 1999. Global stock markets in the twentieth century. Journal of Finance. 54(3). Pp:953-980

Kabiru, James Ndungu, Duncan Elly Ochieng and Hellen Wairimu Kinyua. 2015. The Effect of General Elections on Stock at The Nairobi Securities Exchange. European Scientific Journal. 11(28). Pp:435-460

Kemala, Kadek Citra dan I. G. K. Agung Ulupui. 2015. Reaksi Pasar Terhadap Publikasi Annual Report Award. E-Jurnal Akuntansi Universitas Udayana. 11(1). h:171-185

Kiremu, Mercy K. G., Nebat G., Adholpus W., James K. M. 2013. Stock Price and Volumes Reaction to Annual Earnings Announcement: A Case of the Nairobi Securities Exchange. International Journal of Business, Humanities and Technology. 3(2). Pp:100-111

Kuria, A. M. and George K. Riro. 2013. Stock Market Anomalies: A Study of Seasonal Effects on Average Returns of Nairobi Securities Exchange. Research Journal of Finance and Accounting. 4(7). Pp:207-215

Liogu, Stesia Juliana dan Ivonne S. Saerang. 2015. Reaksi Pasar Modal Terhadap PengumumanKenaikanHarga BBM Atas Saham LQ 45 Pada Tanggal1 November 2014. Jurnal EMB,. 3 (1): h:1274-1282

Marisca, Evi dan TrisnadiWijaya. 2013. Analisis Perbedaan Abnormal Return Sebelum dan Sesudah Pengumuman Kenaikan Harga BahanBakar Minyak (BBM) di Perusahaan LQ45. e-jurnal manajemen. h:1-10

Marzuki, Usman. 1989. Pasar Modal Sebagai Piranti untuk Mengalokasi Sumberdaya Ekonomi Secara Optimal Management \& Usahawan Indonesia. No. 10 Thn XVIII.

Munawarah, 2009. Analisis Perbandingan Abnormal Return dan Trading Volume Activity Pada Saham LQ-45 Sebelum dan Sesudah Suspend BEI (Studi Kasus Indeks LQ-45 di Bursa Efek Indonesia). Universitas Diponegoro. Semarang

Nazir, Mian Sanjid, Hassan Younus, Ahmad Kaleem, and Zeshan Anwar. 2014. Impact of political events on stock market returns: empirical evidence from 
Pakistan. Journal of Economic and Administrative Sciences. 30(1). Pp: 6078

Neni, Meidawati dan Mahendra Harimawan. 2004. Pengaruh Pemilihan Umum Legislatif Indonesia Tahun 2004 Terhadap Return Saham dan Volume Perdagangan Saham LQ45 di PT. Bursa Efek Jakarta (BEJ). Sinergi Kajian Bisnis dan Manajemen. 7(1) ha:89-101

Nurwanto. 2004. Reaksi Pasar Modal terhadapPeristiwa Bom Bali, Bom Makasar, dan Bom Mariot (study kasus di BEJ denganProksi Saham-saham LQ 45). Magister Manajemen Universitas Diponogoro. Semarang.

Oktaviani, R. H., Topowijono dan Sri Sulasmiyati. 2016. Analisis Perbedaan Trading Volume Activity dan Abnormal Return Sebelum dan Sesudah Pengumuman Buy Back Saham. Jurnal Administrasi Bisnis(JAB). 33(1). h:120-126

Purnamawati, I Gusti Ayu \& Desak Nyoman Sri Werastuti. 2013. Faktor Fundamental Ekonomi Makro terhadap Harga Saham LQ45. Jurnal Keuangan dan Perbankan, 17(2) h: 211-219.

Rahmawati dan Tri Suryani, 2005, "Over Reaksi Pasar Terhadap Harga Saham Perusahaan Manufaktur Di Bursa Efek Jakarta". Seminar Nasional Akuntansi ke 8, Solo, 15-16 September 2005.

Rahmawati, Ika Yustina dan Tiara Pandansari. 2016. Reaksi Pasar Modal Dari Dampak Peristiwa Bom Plaza Sarinah Terhadap Abnormal Return Perusahaan LQ45 Yang Terdaftar di BEI. Riset Akuntansi dan Keuangan Indonesia. 1(2). h:126-133

Rakhimsyah dan Gunawan. 2011. Pengaruh Keputusan Investasi, Keputusan Pendanaan, Kebijakan Deviden dan Tingkat Suku Bunga Terhadap Nilai Perusahaan. Jurnal Investasi. Vol. 7 No. 1 Hal. 31-45.

Respati, Novita WeningTyas. 2014. Reaksi Pasar Modal Terhadap Pengumuman Sengketa Hasil Pemilihan Presiden 2014. JSAI. 1(1) h:12-20

Samsul, Muhammad. 2006. Pasar Modal dan Manajemen Portofolio. Jakarta: Erlangga

Santoso, Singgih. 2001. Statistik Non Parametrik. Jakarta: PT Elex Media

Sirait, R. S., Wiwik Tiswiyanti dan Fitrini Mansur. 2012. Dampak Pergantian Menteri Keuangan RI Tahun 2010 Terhadap Abnormal Return Perusahaan Perbankan Yang Terdaftar di BEI. e-Jurnal BINAR Akuntansi. 1(1) h:15-22 
Sugiyono. 2013. Metode Penelitian dan Bisnis. Bandung: Alfabeta

Sulaiman, Wahid. 2002. Statistik Non-Parametrik, Contoh Kasus dan Pemecahannya dengan SPSS. Yogyakarta: Andi.

Sularso Andi R. 2003. Pengaruh Pengumuman DividenTerhadap Perubahan Harga Saham (return) Sebelum Dan Sesudahex -Dividend Date Di Bursa Efek Jakarta (BEJ). Jurnal Akuntansi. Universitas Jember. Vol. 5. No. 1.

Sularso, A. 2003. "Pengaruh Pengumuman Dividen Terhadap Perubahan Harga Saham (Return) Sebelum dan Sesudah Ex-Devidend Date di Bursa Efek Jakarta (BEJ)". Jurnal Akuntansi dan Keuangan: Vol. 5 No. 1, hal. 1-17.

Suparsa, I. M. Joni dan N. M. Dwi Ratnadi. 2014. Perbedaan Abnormal Return dan Trading Volume Activity Atas Pengumuman Kenaikan Harga BBM Pada Saham Yang Tergolong LQ45. E-Jurnal Akuntansi Universitas Udayana. 7(2). h:382-389

Sutrisno. 2000. Manajemen Keuangan. Edisi Satu. Yokyakarta: Ekonisia

Telaumbanua \& Sumiyana. 2008. Pengumuman Laba Terhadap Reaksi Pasar Modal: Studi Empiris Bursa Efek Indonesia 2004-2006. Jurnal Manajemen Teori DanTerapan. 1(3)

Tzachi, Z. 2003. Political events and stock market: Evidence from Israel. International Journal of Business. Pp:244-245

Vahini, Yuni Prema dan Nyoman Wijana Asmara Putra. 2015. Event Study: Analisis Reaksi Investor Pada Publikasi Laporan Keuangan Tahunan. EJurnal Akuntansi Universitas Udayana. 13(2). h:387-404

Wabwire, J. M., George O., Samuel O., and Amos N. 2013. The Effect of Initial Public Offer Announcements on Market Returns of Listed Stocks at The Nairobi Stock Exchange. International Journal of Research in Management. 4. Pp:84-119

Wardhani, Laksmi Swastika. 2013. Reaksi Pasar Modal Indonesia Terhadap Peristiwa Pemilihan Gubernur DKI Jakarta Putaran II 2012 (event study pada saham anggota Indeks KOMPAS 100). Skripsi Manajemen Fakultas Ekonomi dan Bisnis Universitas Brawijaya.

Yuwono, Andri. 2013. Reaksi Pasar Modal di BEI Terhadap Pengumuman Peristiwa Bencana Banjir Yang Melanda DKI Jakarta Tahun 2013. Jurnal Nominal. 2(2) h:135-150 